\title{
Sea level trend and variability around Peninsular Malaysia
}

\author{
Q. H. Luu, P. Tkalich, and T. W. Tay \\ Tropical Marine Science Institute, National University of Singapore, Singapore \\ Correspondence to: Q. H. Luu (tmslqh@ nus.edu.sg)
}

Received: 16 April 2014 - Published in Ocean Sci. Discuss.: 17 June 2014

Revised: 26 June 2015 - Accepted: 3 July 2015 - Published: 4 August 2015

\begin{abstract}
Sea level rise due to climate change is nonuniform globally, necessitating regional estimates. Peninsular Malaysia is located in the middle of Southeast Asia, bounded from the west by the Malacca Strait, from the east by the South China Sea (SCS), and from the south by the Singapore Strait. The sea level along the peninsula may be influenced by various regional phenomena native to the adjacent parts of the Indian and Pacific oceans. To examine the variability and trend of sea level around the peninsula, tide gauge records and satellite altimetry are analyzed taking into account vertical land movements (VLMs).

At annual scale, sea level anomalies (SLAs) around Peninsular Malaysia on the order of 5-25 cm are mainly monsoon driven. Sea levels at eastern and western coasts respond differently to the Asian monsoon: two peaks per year in the Malacca Strait due to South Asian-Indian monsoon; an annual cycle in the remaining region mostly due to the East Asian-western Pacific monsoon. At interannual scale, regional sea level variability in the range of $\pm 6 \mathrm{~cm}$ is correlated with El Niño-Southern Oscillation (ENSO). SLAs in the Malacca Strait side are further correlated with the Indian Ocean Dipole (IOD) in the range of $\pm 5 \mathrm{~cm}$. Interannual regional sea level falls are associated with El Niño events and positive phases of IOD, whilst rises are correlated with La Niña episodes and negative values of the IOD index. At seasonal to interannual scales, we observe the separation of the sea level patterns in the Singapore Strait, between the Raffles Lighthouse and Tanjong Pagar tide stations, likely caused by a dynamic constriction in the narrowest part.

During the observation period 1986-2013, average relative rates of sea level rise derived from tide gauges in Malacca Strait and along the east coast of the peninsula are $3.6 \pm 1.6$ and $3.7 \pm 1.1 \mathrm{~mm} \mathrm{yr}^{-1}$, respectively. Correcting for respective VLMs $\left(0.8 \pm 2.6\right.$ and $\left.0.9 \pm 2.2 \mathrm{~mm} \mathrm{yr}^{-1}\right)$, their corresponding geocentric sea level rise rates are estimated at
\end{abstract}

$4.4 \pm 3.1$ and $4.6 \pm 2.5 \mathrm{~mm} \mathrm{yr}^{-1}$. The geocentric rates are about $25 \%$ faster than those measured at tide gauges around the peninsula; however, the level of uncertainty associated with VLM data is relatively high. For the common period between 1993 and 2009, geocentric sea level rise values along the Malaysian coast are similar from tide gauge records and satellite altimetry ( 3.1 and $2.7 \mathrm{~mm} \mathrm{yr}^{-1}$, respectively), and arguably correspond to the global trend.

\section{Introduction}

It is well established that global mean sea level (GMSL) has been rising since the beginning of the last century (IPCC, 2013). Primary contributors to the contemporary sea level rise are increases of ocean temperature and ice sheet melting, modulated by regional to global factors such as variability in ocean circulation, El Niño-Southern Oscillation (ENSO) and Pacific Decadal Oscillation (Stammer et al., 2013).

Temporal and spatial variability of sea level complicates estimation of sea level rise rates at regional and global scales (e.g. Nerem et al., 2006; Jevrejeva, 2008; Church and White, 2011; Hay et al., 2015). Reconstructing the GMSL from tide gauges using stationary empirical orthogonal functions based on satellite observation, Church and White (2011) derived the rate $1.7 \pm 0.2 \mathrm{~mm} \mathrm{yr}^{-1}$ for the period 1900-2009, which was adopted by IPCC (2013) and many others (e.g. Meyssignac and Cazenave, 2012; Stammer et al., 2013). In a recent statistical analysis, Hay et al. (2015) applied the Kalman smoothing technique and suggested a lower rate, $1.2 \pm 0.2 \mathrm{~mm} \mathrm{yr}^{-1}$. Acceleration of sea level rise since the early 20th century is commonly accepted according to Church and White (2011) as $0.01 \mathrm{~mm} \mathrm{yr}^{-12}$, revised by Hay et al. (2015) as $0.017 \mathrm{~mm} \mathrm{yr}^{-12}$. The rates have increased recently and are similar from both ap- 
proaches. For the period between 1993 and 2009 when satellite measurements are available, in situ data from tide gauges displayed the rate of $2.8 \pm 0.8 \mathrm{~mm} \mathrm{yr}^{-1}$ (Church and White, 2011), whilst altimetry suggested a consistent rate of $3.3 \pm 0.4 \mathrm{~mm} \mathrm{yr}^{-1}$ (Nicholls and Cazenave, 2010). The same rate of $3.0 \pm 0.7 \mathrm{~mm} \mathrm{yr}^{-1}$ for a similar period $1993-2010$ was recently yielded by Hay et al. (2015).

In the North Pacific and Indian oceans, regional patterns of interannual sea level variability are modulated by ENSO, the North Pacific Decadal Oscillation (Trenberth and Hurrell, 1994; Church et al., 2004; Becker et al., 2012; Tkalich et al., 2013), the North Pacific Subtropical Gyre, easterly trade winds (Merrifield, 2011) and the Walker cell (L'Heureux et al., 2013). For instance, the latest studies (Qiu and Chen, 2011; L'Heureux et al., 2013) suggest that the Walker cell recently strengthened, resulting in a mean sea level rise along the western tropical Pacific coasts at a rate of $30 \mathrm{~mm} \mathrm{yr}^{-1}$ for the period 1993-2001 (Church et al., 2006; Becker et al., 2012).

Peninsular Malaysia is located at the centre of Sunda Shelf, encompassed from the east by the South China Sea (SCS), which is the largest marginal sea in the Pacific Basin, and from the west by the Andaman Sea of the Indian Ocean (Fig. 1). As a result, sea level along the Malaysian coast is affected by various phenomena relevant to the extended region. Around the peninsula, especially in the Malacca Strait, synoptic analysis of seasonal sea level has yet to be done.

Seasonal sea level variability across the SCS is predominantly driven by the Asian monsoonal wind (Wyrtki, 1961; Lau et al., 1998; Ding and Johnny, 2005; Tan et al., 2006; Wang et al., 2009; Liang and Evans, 2011). Along Peninsular Malaysia, the Asian monsoon branches into two major parts: the East Asian-western Pacific (EAWP) monsoon (Li and Zeng, 2002) and the South Asian-Indian (SAI) monsoon (Goswami et al., 1999; Wang and Fan, 1999). These monsoon systems affect their respective regions quite independently (Liang and Evans, 2011). Along the east coast of the peninsula, positive seasonal sea level anomalies (SLAs) are induced by wind shear during the north-east (NE) monsoon (boreal winter), whilst negative anomalies are caused by the south-west (SW) monsoon (boreal summer; Tkalich et al., 2012; Chen et al., 2012). At the intermediate area represented by Singapore Strait, the seasonal SLA caused by the monsoonal wind may reach $\pm 20 \mathrm{~cm}$ (Tkalich et al., 2013).

In the SCS, the interannual variability of mean sea level (MSL) exhibits a strong signature of ENSO due to intrusion of the Kuroshio Current through the Luzon Strait, coupled with atmospheric teleconnection (Qu et al., 2004; Wang et al., 2006; Cheng and Qi, 2007; Rong et al., 2007; Chen et al., 2012; Tkalich et al., 2013; Peng et al., 2013; Nidheesh et al., 2013). The correlation with ENSO becomes stronger towards the southern part of the SCS (Rong et al., 2007; Peng et al., 2013). It is not a surprise that interannual SLAs around Peninsular Malaysia are greatly affected by ENSO. In the Singapore Strait, SLAs derived from tide gauge records

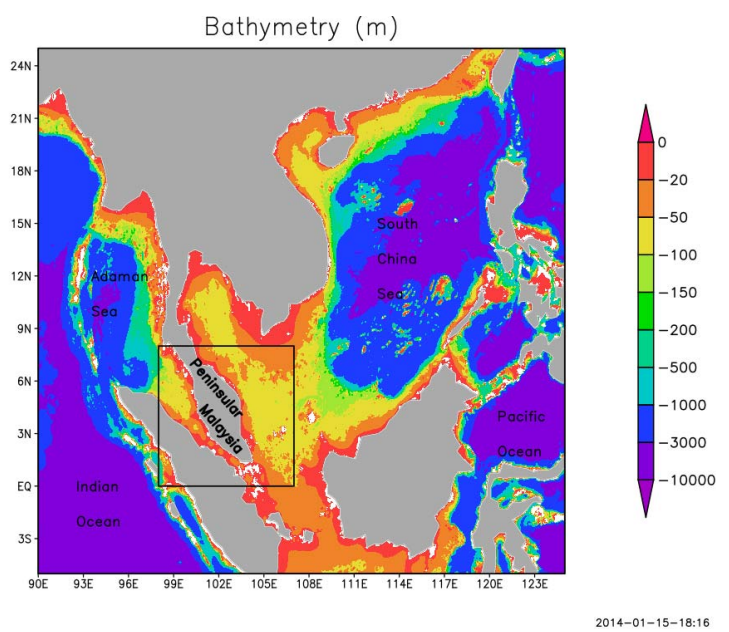

Figure 1. Bathymetry in the region with the black box indicating area of interest.

(1984-2011) are highly correlated (-0.7) with the multivariate ENSO index (MEI), with falls and rises of mean sea level associated with El Niño and La Niña episodes being on the order of $\pm 5 \mathrm{~cm}$ (Tkalich et al., 2013). In the Bay of Bengal and the Andaman Sea adjacent to the west coast of the peninsula, the range of anomalies accompanying ENSO is $\pm 15 \mathrm{~cm}$ (Aparna et al., 2012; Sreenivas et al., 2012). The complete picture of ENSO-related SLAs at both sides of the peninsula is yet to be drawn.

The Bay of Bengal also experiences SLAs induced by the Indian Ocean Dipole (IOD) in the range $\pm 20 \mathrm{~cm}$ (Aparna et al., 2012; Sreenivas et al., 2012; Palanisamy et al., 2014). It is expected that the signature of the IOD is also detectable in the Malacca Strait and decreases toward the Singapore Strait; however, the anomalies have not been quantified.

Sea level trends in areas adjacent to Peninsular Malaysia have been analyzed previously, including the Gulf of Thailand (Trisirisatayawong et al., 2011), the Singapore Strait (Tkalich et al., 2013), the SCS (Peng et al., 2013) and the Indian Ocean (Palanisamy et al., 2014). In the Gulf of Thailand (east of the peninsula), the sea level rise rate $3.0 \pm 1.5 \mathrm{~mm} \mathrm{yr}^{-1}$ during the period 1940-2004 was derived by Trisirisatayawong et al. (2011) combining tide gauge data and vertical land movement (VLM) correction. In the Singapore Strait, relative sea level rise rates of $1.2-1.7 \mathrm{~mm} \mathrm{yr}^{-1}$ during 1975-2009 and 1.8-2.4 $\mathrm{mm} \mathrm{yr}^{-1}$ during 1984-2009 were obtained by Tkalich et al. (2013). In the entire SCS, two-dimensional sea level reconstruction since 1950 completed by Meyssignac et al. (2012) and satellite altimetry were used by Peng et al. (2013) to analyze sea level trends. For the period between 1993 and 2009, it was found that the reconstructed sea levels in the SCS exhibited an average rise rate of $3.6 \pm 0.4 \mathrm{~mm} \mathrm{yr}^{-1}$, which was similar to the satellite altimetry rate of $3.9 \pm 0.6 \mathrm{~mm} \mathrm{yr}^{-1}$. On average, the rate in 1950-2009 was estimated as $1.7 \pm 0.1 \mathrm{~mm} \mathrm{yr}^{-1}$, which is 
slightly lower than the global trend $\left(1.8 \pm 0.1 \mathrm{~mm} \mathrm{yr}^{-1}\right)$. In the Indian Ocean, the rate of $1.5 \mathrm{~mm} \mathrm{yr}^{-1}$ during the period 1950-2009 was derived by Palanisamy et al. (2014). In summary, all these studies indicate that the sea level trend and variability around Peninsular Malaysia may be highly complicated, non-uniform and considerably different from the global trend, as summarized in Table 1.

The largest uncertainty in sea level trend assessment is arguably introduced by VLM. This vertical displacement is due to the rise of landmass associated with glacial isostatic adjustment (GIA) rebound, regional active tectonic movement, anthropogenic impact of underground water or sediment compaction, and other phenomena. To correct tide gauge data for VLM, the first approach (e.g. Peltier, 2004; Church and White, 2006, 2011) allows one to estimate viscoelastic adjustment due to ongoing rebound following the retreat of past ice sheets. However, it is limited not only due to the parameterization (and hence accuracy) in each GIA model, but also due to the fact that other local sources of the vertical motion such as local crustal displacement, having the same magnitude in many areas, have not been taken into account (Tamisiea and Mitrovica, 2011; Santamaría-Gómez et al., 2012). The geodetic approach becomes more promising, as it measures land displacement directly from Global Positioning System (GPS) stations, and occasionally from Doppler Orbitography and Radiopositioning Integrated by Satellite (DORIS) or from absolute gravity stations (Wöppelman et al., 2007, 2009, 2014; Santamaría-Gómez et al., 2012, 2014).

At Peninsular Malaysia, the VLM pattern is highly complex as a result of drift of the Sundaland Block, Australian Plate and Indian Plate on the Earth's mantle. VLM ranges between a subsidence rate of $0.60 \pm 2.89 \mathrm{~mm} \mathrm{yr}^{-1}$, and an uplift of $1.70 \pm 1.90 \mathrm{~mm} \mathrm{yr}^{-1}$ (Simons et al., 2007), being of the same order as the regional sea level rise rate. Unsurprisingly, the relative rate $2-3 \mathrm{~mm} \mathrm{yr}^{-1}$ obtained by Peng et al. (2013) for the period 1993-2009, ignoring the VLM in the Gulf of Thailand, is half of the geocentric rate 3.5$4.5 \mathrm{~mm} \mathrm{yr}^{-1}$ computed by Trisirisatayawong et al. (2011). Recently, Palanisamy et al. (2014) have taken into account VLM in evaluating the sea level rise rate in the Indian Ocean. However, no GPS station in the Malacca Strait region was used, leaving the estimation of a geocentric rate west of the peninsula unsolved.

It is evident that the past analyses of sea level in the region and particular around Peninsular Malaysia were incomplete and fragmentary in terms of spatial and temporal coverage, as well as methodologically inappropriate, leading to inconsistent estimations of sea level trends. Meanwhile, understanding of the phenomenon is important not only for several neighbour countries (Malaysia, Indonesia and Singapore) but also as a component of the world map of sea level rise.

This paper examines sea level trend and variability around Peninsular Malaysia using tide gauge data combined with local VLM information and satellite altimetry. Section 2

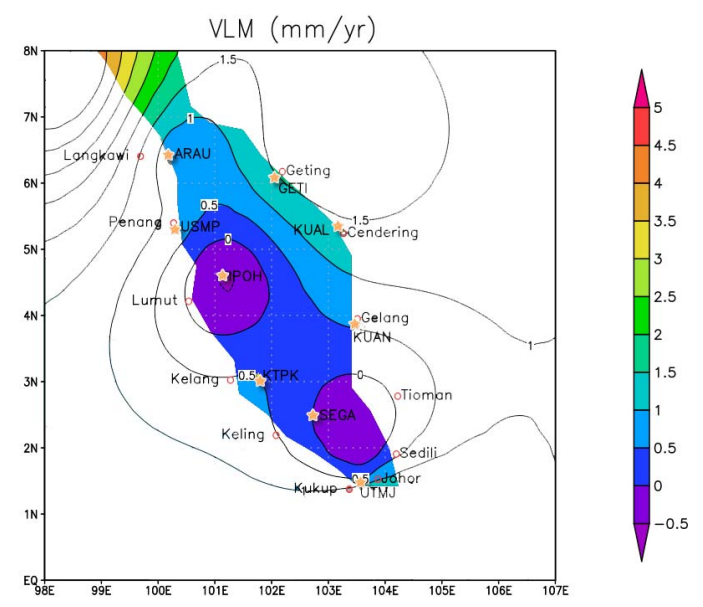

GrADS: IGES/COLA

2014-01-17-16:24

Figure 2. Locations of and GPS stations (yellow symbols) extracted from Simons et al. (2007) and tidal gauge stations (red circles) archived from PSMSL along the coasts of Peninsular Malaysia. Contours represent VLM rates $\left(\mathrm{mm} \mathrm{yr}^{-1}\right)$; positive VLM value shows upward direction.

presents data processing methodology, followed by results for the sea level variability and long-term trends in Sect. 3. The findings are summarized in the last section and compared with the global trends.

\section{Data and methodology}

The annual and monthly sea level data for 12 considered research-quality tide gauges in the domain of interest were obtained from the Permanent Service for Mean Sea Level (PSMSL; http://www.psmsl.org/data/obtaining/; Holgate et al., 2013). The data passed quality control and have more than 20 years of records having gaps less than $30 \%$ of total length. The selected tide gauges are evenly positioned along the peninsular coast (Figs. 2 and 3) clustered in two regions - west and east, namely, six stations in the Malacca Strait (Langkawi, Pinang, Lumut, Kelang, Keling and Kukup) and the same number along the east coast of Peninsular Malaysia (Geting, Cendering, Gelang, Tioman, Sedili and Johor Bahru). Four stations in the (intermediate) Singapore waters (Sultan Shoal, Raffles Lighthouse, Tanjong Pagar and Sembawang) are also used for a comparison (after Tkalich et al., 2013).

A first glance at the data revealed gaps in the records of all 12 considered tide gauges, for instance, Johor station missed more than $25 \%$ of data since 1984 . For data with strong seasonal variability, even a 1-month gap necessitates removal of the respective year out of the analysis; however, the gappy years cannot be simply neglected because an annual increment due to sea level rise could be much smaller than annual and interannual sea level variability (Douglas, 2001; Wahl et al., 2010: Becker et al., 2012). To fill the gappy 
Table 1. Linear trends $\left(\mathrm{mm} \mathrm{yr}^{-1}\right)$ of sea level rise and VLM rates over selected periods.

\begin{tabular}{|c|c|c|c|c|c|c|c|c|}
\hline \multirow{3}{*}{$\begin{array}{l}\text { Source of record } \\
\text { (location) }\end{array}$} & \multirow[b]{3}{*}{ Period } & \multicolumn{4}{|c|}{$\begin{array}{c}\text { Sea level rise rate } \\
\text { from tide gauge record }\end{array}$} & \multicolumn{2}{|c|}{$\begin{array}{l}\text { Sea level rise rate } \\
\text { from satellite }\end{array}$} & \multirow{3}{*}{$\begin{array}{c}\text { VLM rate }^{\mathrm{b}} \\
1994-2004\end{array}$} \\
\hline & & \multicolumn{2}{|c|}{ Entire period } & \multicolumn{2}{|c|}{ 1993-2009 } & \multirow[t]{2}{*}{ 1993-2013 } & \multirow[t]{2}{*}{ 1993-2009 } & \\
\hline & & Relative & Geocentric $^{d}$ & Relative & Geocentric $^{d}$ & & & \\
\hline Langkawi $\left(99^{\circ} 46^{\prime} \mathrm{E}, 6^{\circ} 26^{\prime} \mathrm{N}\right)$ & 1986-2013 & $3.7 \pm 1.9$ & $5.1 \pm 3.3$ & $1.9 \pm 4.2$ & $3.3 \pm 5.0$ & $3.6 \pm 2.1$ & $2.2 \pm 2.9$ & $1.4 \pm 2.7$ \\
\hline Pinang $\left(100^{\circ} 21^{\prime} \mathrm{E}, 5^{\circ} 27^{\prime} \mathrm{N}\right)$ & $1986-2013$ & $4.2 \pm 1.8$ & $5.0 \pm 4.1$ & $3.4 \pm 4.3$ & $4.2 \pm 5.7$ & $3.8 \pm 2.1$ & $2.1 \pm 2.8$ & $0.8 \pm 3.7$ \\
\hline Lumut $\left(100^{\circ} 37^{\prime} \mathrm{E}, 4^{\circ} 14^{\prime} \mathrm{N}\right)$ & $1985-2013$ & $1.9 \pm 1.8$ & $1.8 \pm 3.2$ & $1.8 \pm 3.6$ & $1.7 \pm 4.5$ & $5.0 \pm 2.3$ & $3.0 \pm 3.0$ & $-0.1 \pm 2.7$ \\
\hline Kelang $\left(101^{\circ} 21^{\prime} \mathrm{E}, 3^{\circ} 03^{\prime} \mathrm{N}\right)$ & $1984-2013$ & $2.8 \pm 1.7$ & $3.3 \pm 2.9$ & $2.1 \pm 4.0$ & $2.6 \pm 4.6$ & $5.0 \pm 2.2$ & $3.0 \pm 2.9$ & $0.5 \pm 2.3$ \\
\hline Keling $\left(102^{\circ} 09^{\prime} \mathrm{E}, 2^{\circ} 13^{\prime} \mathrm{N}\right)$ & $1985-2013$ & $2.9 \pm 1.6$ & $3.4 \pm 2.8$ & $2.1 \pm 3.7$ & $2.6 \pm 4.3$ & $4.9 \pm 1.8$ & $4.0 \pm 2.7$ & $0.5 \pm 2.3$ \\
\hline Kukup $\left(103^{\circ} 27^{\prime} \mathrm{E}, 1^{\circ} 20^{\prime} \mathrm{N}\right)$ & $1986-2013$ & $3.6 \pm 1.4$ & $5.0 \pm 2.5$ & $3.4 \pm 3.4$ & $4.7 \pm 3.8$ & $2.4 \pm 2.1$ & $2.0 \pm 3.1$ & $1.4 \pm 2.0$ \\
\hline Malacca Strait & 1986-2013 & $3.6 \pm 1.6$ & $4.4 \pm 3.1$ & $2.4 \pm 3.7$ & $3.2 \pm 4.6$ & $4.1 \pm 1.9$ & $2.7 \pm 2.7$ & $0.8 \pm 2.6$ \\
\hline Johor $\left(103^{\circ} 48^{\prime} \mathrm{E}, 1^{\circ} 28^{\prime} \mathrm{N}\right)$ & $1984-2013$ & $3.3 \pm 1.1$ & $4.5 \pm 2.3$ & $2.4 \pm 1.1$ & $3.6 \pm 2.3$ & $2.5 \pm 1.9$ & $1.9 \pm 2.7$ & $1.2 \pm 2.0$ \\
\hline Sedili $\left(104^{\circ} 07^{\prime} \mathrm{E}, 1^{\circ} 56^{\prime} \mathrm{N}\right)$ & $1987-2013$ & $3.4 \pm 1.2$ & $3.7 \pm 2.4$ & $1.8 \pm 1.2$ & $2.1 \pm 2.4$ & $3.5 \pm 1.6$ & $2.6 \pm 2.2$ & $0.3 \pm 2.1$ \\
\hline Tioman $\left(104^{\circ} 08^{\prime} \mathrm{E}, 2^{\circ} 48^{\prime} \mathrm{N}\right)$ & $1986-2013$ & $3.7 \pm 1.2$ & $4.0 \pm 2.6$ & $2.6 \pm 1.2$ & $2.9 \pm 2.6$ & $4.6 \pm 1.2$ & $3.3 \pm 1.5$ & $0.3 \pm 2.3$ \\
\hline Gelang $\left(103^{\circ} 26^{\prime} \mathrm{E}, 3^{\circ} 59^{\prime} \mathrm{N}\right)$ & 1984-2013 & $3.4 \pm 1.2$ & $4.0 \pm 2.7$ & $3.0 \pm 1.2$ & $3.6 \pm 2.7$ & $4.4 \pm 1.2$ & $3.1 \pm 1.6$ & $0.6 \pm 2.4$ \\
\hline Cendering $\left(103^{\circ} 11^{\prime} \mathrm{E}, 5^{\circ} 16^{\prime} \mathrm{N}\right)$ & $1985-2013$ & $3.8 \pm 1.1$ & $5.2 \pm 1.8$ & $2.2 \pm 1.1$ & $3.6 \pm 1.8$ & $4.6 \pm 1.2$ & $2.9 \pm 1.3$ & $1.4 \pm 1.5$ \\
\hline Geting $\left(102^{\circ} 06^{\prime} \mathrm{E}, 6^{\circ} 14^{\prime} \mathrm{N}\right)$ & 1987-2013 & $3.5 \pm 1.4$ & $5.1 \pm 3.0$ & $1.0 \pm 1.4$ & $2.7 \pm 3.0$ & $4.3 \pm 1.3$ & $2.6 \pm 1.6$ & $1.6 \pm 2.7$ \\
\hline East coast of Peninsular Malaysia & $1986-2013$ & $3.7 \pm 1.1$ & $4.6 \pm 2.5$ & $2.2 \pm 2.0$ & $3.1 \pm 3.0$ & $4.0 \pm 1.2$ & $2.7 \pm 1.6$ & $0.9 \pm 2.2$ \\
\hline Singapore Strait $^{\mathrm{e}}$ & 1984-2011 & $3.5 \pm 1.2$ & $3.8 \pm 1.2$ & & & & & $0.3 \pm 0.1^{\mathrm{c}}$ \\
\hline Gulf of Thailand ${ }^{\mathrm{f}}$ & 1940-2004 & & $3.0 \pm 1.5$ & & & & $3.6 \pm 0.7$ & \\
\hline South China Sea ${ }^{g}$ & $1950-2009$ & $1.7 \pm 0.1$ & & $3.6 \pm 0.4$ & & & $3.9 \pm 0.6$ & \\
\hline $\begin{array}{l}\text { Global reconstruction (EOF) } \\
\text { using tide gauges } \mathrm{h}\end{array}$ & 1900-2009 & & $1.7 \pm 0.2$ & & $2.8 \pm 0.8$ & & & \\
\hline $\begin{array}{l}\text { Global reconstruction (KS) } \\
\text { using tide gauges }{ }^{i}\end{array}$ & $1901-1990$ & & $1.2 \pm 0.2$ & & $3.0 \pm 0.7^{\mathrm{j}}$ & & & \\
\hline Global altimetry & $1993-2013$ & & & & & $3.2 \pm 0.4^{\mathrm{k}}$ & $3.3 \pm 0.4^{1}$ & \\
\hline
\end{tabular}

Uncertainties are calculated at the $95 \%$ confidence level. ${ }^{\text {a }}$ Sea level rise rate obtained from AVISO satellite altimetry data; ${ }^{\mathrm{b}}$ VLM rates and uncertainties in Peninsular Malaysia are interpolated from Simons et al. (2007); ${ }^{\mathrm{c}}$ VLM rate and uncertainty in the Singapore Strait is calculated from data from NTUS GPS station for the period 1997-2011, available at

http://www.sonel.org/spip.php?page $=$ gps\&idStation $=765 ;{ }^{\mathrm{d}}$ assume that VLM speed is constant beyond its observational period; ${ }^{\mathrm{e}}$ Tkalich et al. (2013); ${ }^{\mathrm{f}}$ Trisirisatayawong et al. (2011) at Ko Lak tide gauge; ${ }^{\mathrm{g}}$ Peng et al. (2013); ${ }^{\mathrm{h}}$ reconstruction using the Empirical Orthogonal Function (EOF) method, Church and White (2011); ${ }^{\mathrm{i}}$ reconstruction using the Kalman smoothing (KS) method, Hay et al. (2015). ${ }^{j}$ Hay et al. (2015) estimate for similar period (1993-2010); ${ }^{\mathrm{k}}$ Data provided at http://sealevel.colorado.edu - Nerem et al. (2010); ${ }^{1}$ Nicholls and Cazenave (2010).

years, the missing data points were replaced by an average of de-trended sea level values in the same year from its two neighbouring tide gauges. This reconstruction technique is expected to be applicable due to the similarity in sea level patterns at nearby stations along the Malaysian coast, evidenced by high correlations (with coefficient $r=0.93-0.98$ ) between them (Fig. 3). To examine the robustness of reconstruction further, fill-in values were compared against known-but-withheld values (Fig. 4a). The root mean square error (RMSE) between these values is small $(1.03 \mathrm{~cm})$, whilst the errors have a Normal distribution and $95 \%$ of them are within the range of $\pm 2 \mathrm{~cm}$.

In both regions, mean sea level for a given year is computed as an average of sea levels after reconstruction (described below) from respective gauges. To assess the accuracy of the reconstruction technique, merged altimetry satellite data (AVISO; http://www.aviso.altimetry.fr/en/data/ products/sea-surface-height-products/global/msla.html)

were used at points closest to tide gauges for the common period 1993-2013 (Fig. 3 and Table 1). Hay et al. (2015) pointed out that sea level response to atmospheric pressure change is negligible at global scale. In this study, we have examined the inverted barometer correction (IBC) as well, but it was not adopted because IBC contribution to regional mean sea level rise is marginal (about $5 \%$ of the rate).

In order to obtain the geocentric sea level rise rate, the tide gauge records have to be corrected for VLM. Since the vertical landmass related to the post-glacial rebound is only a component of the VLM, the GIA model result is not considered in this study. On the other hand, though there are 19 stations listed to measure the land displacements in Malaysia in the ITRF2008 website (http://itrf.ensg.ign.fr/ ITRF_solutions/2008/ITRF2008.php; Altamimi et al., 2011), their GPS data either are unavailable (17 out of 19 stations) or have short (less than a year) records (2 out of 19 stations). Hence, we employed the VLM data published by Simons et al. (2007) which have a 10-year span from nine GPS stations around Peninsular Malaysia. These values were interpolated to tide gauge locations to obtain respective VLM rates (Fig. 2). The VLM data for the Singapore Strait are not publicly available (E. Hill, personal communication, 2015), except the one from NTUS GPS station obtained from SONEL (http://www.sonel.org/spip.php?page=gps\&idStation=765). 

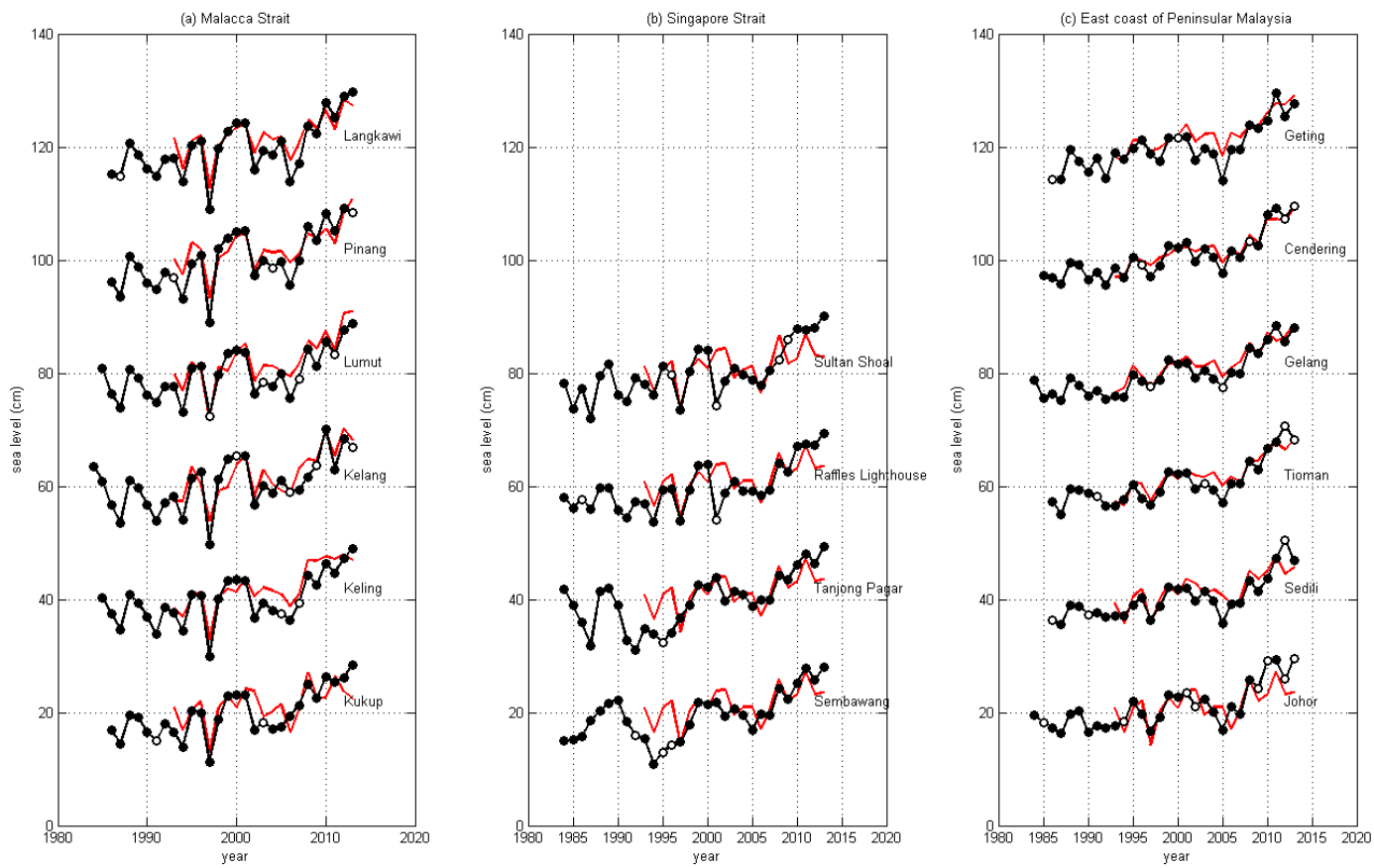

Figure 3. Annual sea level at tide gauges around Peninsular Malaysia: (a) Malacca Strait, (b) Singapore Strait and (c) east coast of the peninsula. Black circles show data from PSMSL; white open circles indicate reconstructed missing data. Red lines represent annual geocentric satellite altimetry data, which are adjusted to the mean level of tide gauge data for the period 1993-2013.
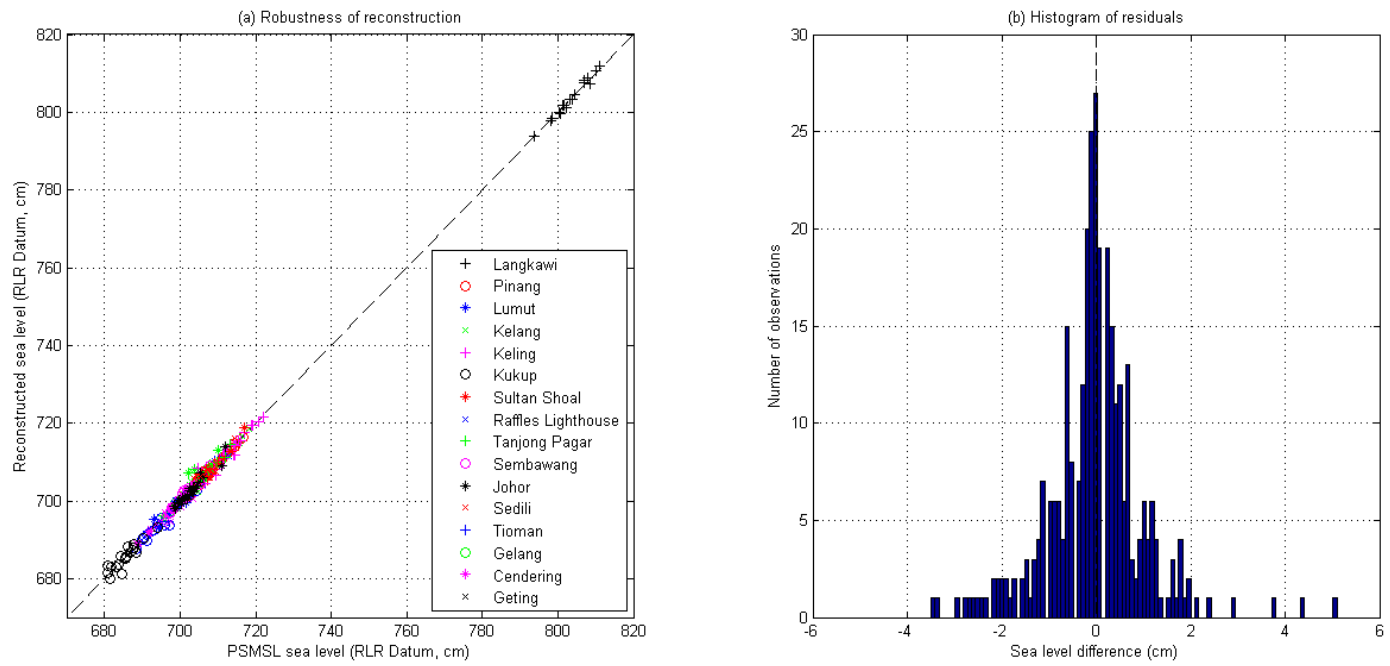

Figure 4. (a) Comparison between reconstructed and observed annual sea level. (b) Histogram of residuals between reconstruction and observation.

In order to correlate the interannual sea level variability with ENSO and IOD phenomena, the MEI (http://www. esrl.noaa.gov/psd/enso/mei/) and Dipole Mode Index (DMI; http://stateoftheocean.osmc.noaa.gov/sur/ind/dmi.php) were used as proxies, respectively. The MEI comprises six physical variables (sea level pressure, zonal and meridional components of the surface wind, sea surface temperature, surface air temperature and total cloudiness fraction of the sky), which have been measured over the North Pacific for many years (Wolter and Timlin, 1993, 1998). The DMI index represents the gradient of anomalous sea surface temperature between two areas: a western pole in the Arabian Sea and an eastern pole in the eastern Indian Ocean south of Indonesia (Saji et al., 1999). To separate the overlapping contributions of ENSO and IOD to SLAs, multiple linear regression analysis was applied with linear predictors MEI and DMI. Note, 
since the DMI data have not been updated, the regression analysis was performed up to the year 2011.

Linear trends were obtained using the least square method with uncertainties calculated at $95 \%$ confidence level (Table 1). Geocentric sea level rise rates were obtained by adding VLM speed to the relative rate. The combined error is calculated as the square root of the sum of squared (relative and VLM) errors. Sea level rise trend and uncertainty are then derived from its annual time series using linear regression analysis. Seasonal (Sa) and semi-annual (Ssa) tidal-like oscillations were obtained from monthly data using harmonic analysis.

To examine the autocorrelation, we applied the DurbinWatson (DW) statistical analysis for de-trended reconstructed data with at least 25 sampling records for each station (Bos et al., 2014). Among 12 tide gauges, 7 stations (namely Pinang, Keling, Kakup, Sedili, Tioman, Gelang and Genting) have $p$ values smaller than 0.05 . It is not surprising that we found no statistical evidence to reject autocorrelation of the de-trended residuals, as all DW values are smaller than the upper critical value 1.45 for one regressor for $95 \%$ confidence level. This behaviour is not unique, since previous studies (Foster and Brown, 2014; Bos et al., 2014) indicated that SLAs from tide gauges often have temporal correlations. We are not original to state that uncertainties in sea level trend assessments may be underestimated, and therefore derived trends need to be interpreted with care.

\section{Results and discussions}

\subsection{Seasonal sea level variability}

Figure 5 presents seasonal SLAs at tide gauges along the coastline of Peninsular Malaysia. Distinct patterns are found along the east coast and the west coast (Malacca Strait) of the peninsula, with an intermediate area in Singapore Strait where both features are observed. Seasonal SLAs along the east coast of Peninsular Malaysia are in the range of $\pm 25 \mathrm{~cm}$, with a single peak and trough observed during NE and SW monsoons, respectively (Fig. 5c). The phenomenon causing the annual cycle has been explained by Tkalich et al. (2012) as being part of the domain response to the reversing monsoon. During (boreal) winter of the EAWP monsoon, the NE wind causes a sea level surge in the Gulf of Thailand and along the east coast of Peninsular Malaysia. During (boreal) summer, the SW monsoon wind pulls water off the Sunda Shelf towards the north-west SCS, leading to a regional fall of sea level. The amplitude of the annual tidal-like constituent (Sa) is dominant in comparison with the semi-annual one (Ssa) as observed in Fig. 6a.

The seasonal anomaly of sea level in the Malacca Strait shows two peaks with similar magnitude $\pm 5 \mathrm{~cm}$ (Figs. 5a and 6a). Peaks are observed during May and November, whilst troughs are seen during February-March and Septem- ber. The complexity of the pattern is arguably due to competition between seasonal wind from the SCS, and wind stress locally established over the Andaman Sea and directed toward the Malacca Strait. Liang and Evans (2011) pointed out that this region is influenced by the SAI monsoon which acts independently from the EAWP monsoon.

Similar cases of distinct sea surface patterns at both sides of an interferential domain were observed at various places (Tsimplis and Woodworth 1994; García-Lafuente et al., 2004; Vinogradov and Ponte, 2010, 2011). Where two regions are connected, a smooth pattern transition is expected. Indeed, Singapore Strait sea level records (Fig. 5b) show transient SLA features typical for both coasts of the peninsula with a node expected between the Raffles Lighthouse and Tanjong Pagar tide stations, most likely at the narrowest part of Singapore Strait.

\subsection{Interannual sea level variability}

For interannual variability of sea level around Peninsular Malaysia, tide gauge records and satellite altimetry are compared in Fig. 3. Some differences between the two data sets are expected due to the following reasons. First, the coarse spatial resolution of AVISO gridded data is $1 / 4^{\circ} \times$ $1 / 4^{\circ}$, whilst tide gauge records reflect local features (e.g. bathymetry, riverine discharges, and coastal dynamics). Second, annual mean sea level values from tide gauges are mainly deduced from hourly records, whilst those from gridded altimetry products are derived from smoothed data having the temporal interval of a day. Lastly, some uncertainties and biases could stem from the fact that the data sources (AVISO and PSMSL) use different instruments (satellite altimeter versus mareograph) and are post-processed by different de-tide (harmonic analysis) tools. In spite of these differences, both data sources show reasonable agreement in the region with respect to the patterns of interannual variability (Fig. 3).

Annual sea level in different parts of the domain (for altimetry and tide gauge data as well) is highly correlated with the ENSO index (MEI) as seen in Figs. 7 and 8. Overall, sea level in the Malacca Strait has a strong correlation $(-0.63)$ with the MEI, being the strongest $(-0.67)$ at Keling tide gauge. The correlations slightly decrease along the east coast of Peninsular Malaysia with average correlations of -0.62 . Prominent negative annual SLAs correspond to extreme El Niño episodes in the years 1987, 1991-1992, 1997, 2002, 2006 and 2009, whilst sea level peaks are tangible during La Niña phases in the years 1988-1989, 1996, 1999 and 2008. In both cases, the magnitudes of annual SLAs are proportional to the intensity of ENSO events. During the extreme periods of El Niño or La Niña, annual sea level may rise or fall by an average $7 \mathrm{~cm}$ in both Malacca Strait and the east coast of Peninsular Malaysia (Fig. 7).

Whilst the ENSO signature is evident in a majority of tide gauge records along the Malaysian coasts, the IOD signal 

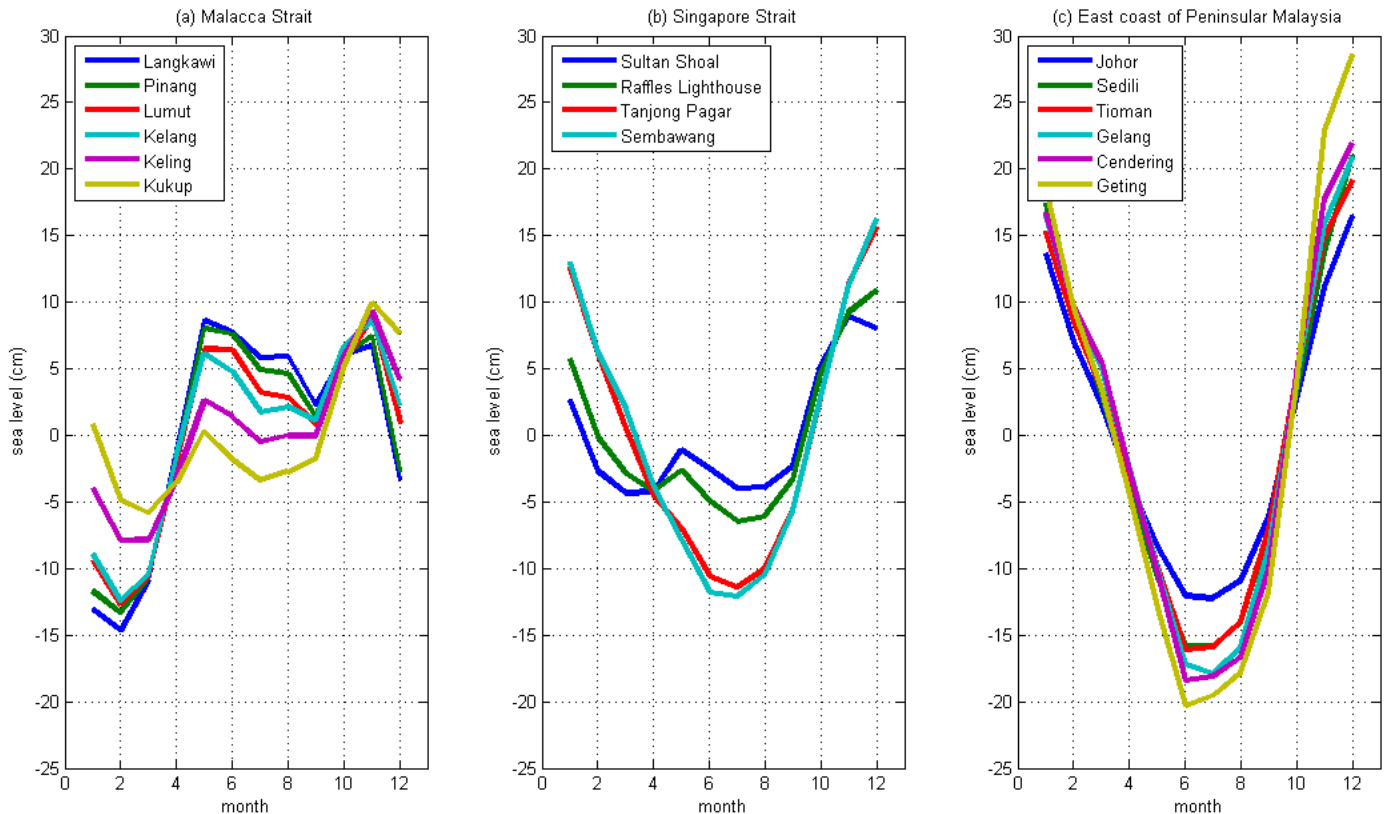

Figure 5. Monthly climatology of SLA in the (a) Malacca Strait, (b) Singapore Strait (after Tkalich et al., 2013), (c) east coast of Peninsular Malaysia. The climatology is derived by taking monthly average at each station over its entire period.

(a)

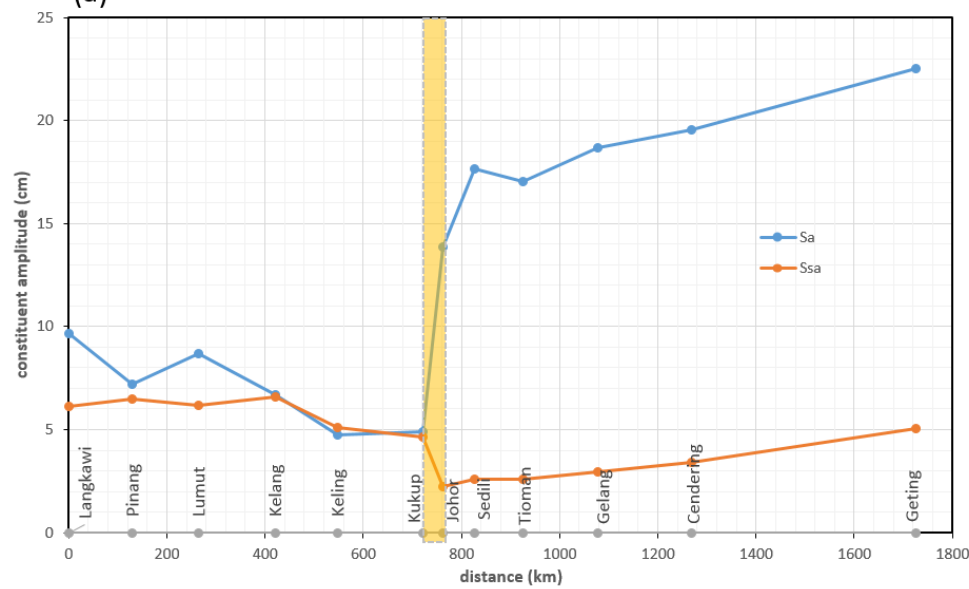

(b)

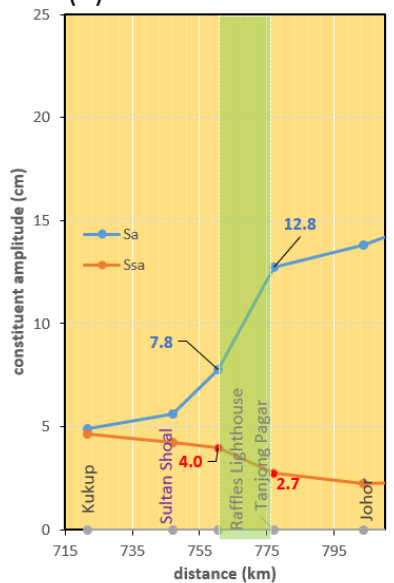

Figure 6. Amplitude of seasonal tidal-like oscillations, denoted by Sa (blue lines) and Ssa (red lines), at tide gauges: (a) along Peninsular Malaysia, and (b) in the Singapore Strait, magnified from yellow shade in (a). The green band shows the transitional region where spatial gradient of amplitude associated with $\mathrm{Sa}$ is the largest. Distance is measured anticlockwise along the peninsular coast.

is detected mainly in the Malacca Strait, with two prominent events linked to the positive phases of IOD in 1994 and 1997. Overall, annual SLAs of up to $5 \mathrm{~cm}$ coincide with the extreme IOD events with correlation coefficient -0.57 (Fig. 7). The exact interaction mechanism of the IOD and local sea level variability is still not fully understood - likely the zonal wind-induced equatorial Kelvin waves generated in the Indian Ocean carry the IOD signal into the Malacca Strait through the Andaman Sea (Clarke and Liu, 1994; Vinaychan- dran et al., 1999; Mutrugudde et al., 2000; Nidheesh et al., 2013).

Correlation between annual sea level in the Malacca Strait and the IOD index (DMI) gradually decreases eastward from the Andaman Sea toward the Singapore Strait, with the coefficient being -0.61 at Langkawi tide gauge, -0.46 at Kukup, and -0.01 at Johor station (Fig. 8a). Zooming in on the Singapore Strait, a sharp reduction in the correlation is observed between Raffles Lighthouse ( -0.52$)$ and Tanjong Pagar $(-0.17)$ stations as shown in Fig. 8b. The phenomenon 

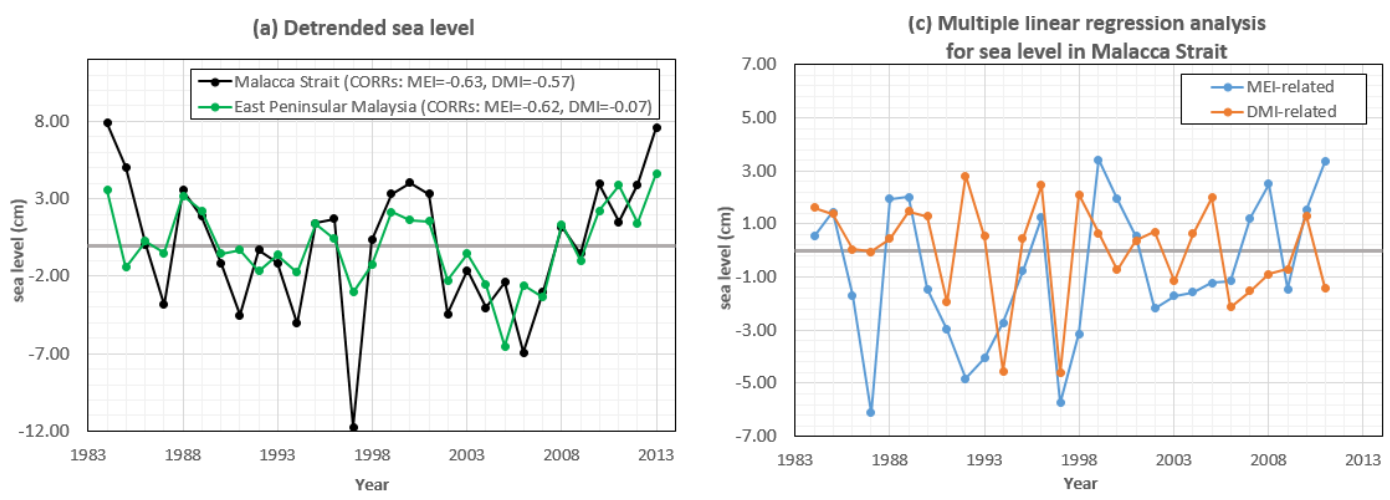

(b) Climate indices
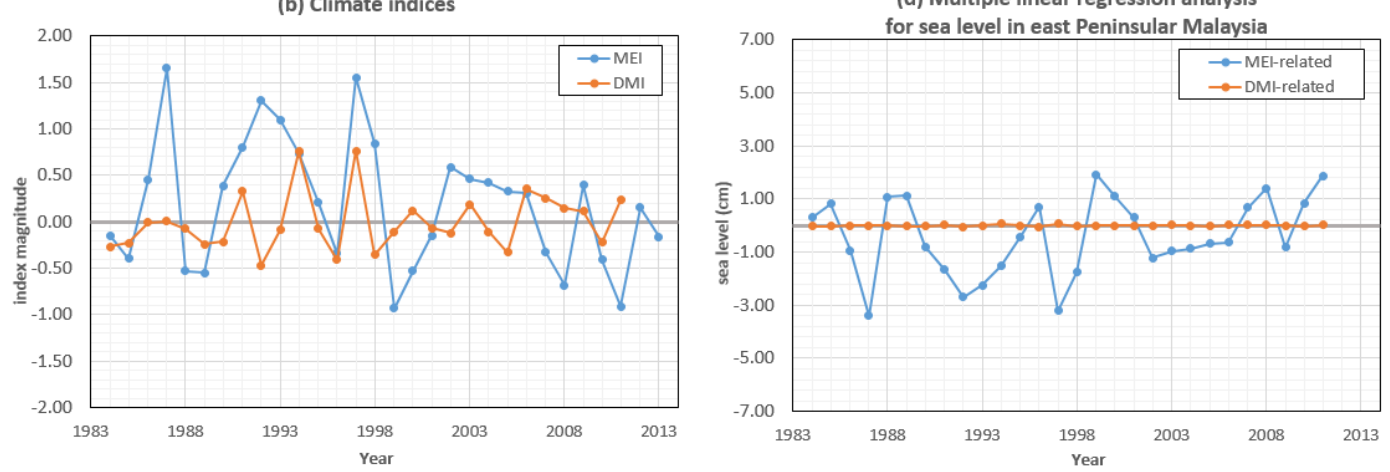

Figure 7. (a) De-trended annual sea levels around Peninsular Malaysia; (b) annual MEI and DMI indices. Sea level changes associated with MEI and DMI in (c) the Malacca Strait, and (d) the east coast of the peninsula, decomposed by multiple linear regression analysis.

(a)

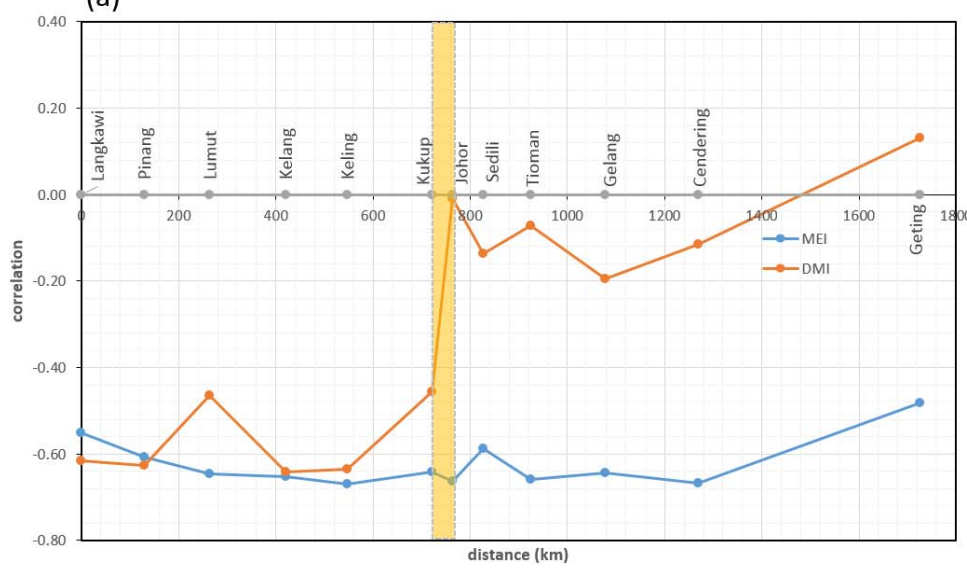

(b)

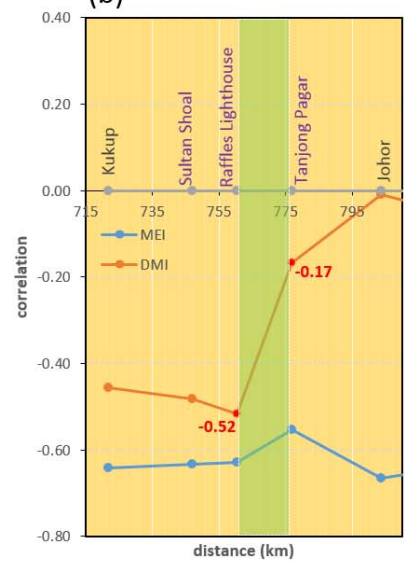

Figure 8. Correlations of interannual SLAs with MEI (blue lines) and DMI (red lines) at tide gauges: (a) along Peninsular Malaysia, and (b) in the Singapore Strait, magnified from yellow shade in (a). The correlation coefficients are computed using de-trended annual sea level from PSMSL (before reconstruction). The green band shows the transitional region where spatial gradient of correlation associated with DMI is the largest. Distance is measured anticlockwise along the peninsula coast.

is consistent with the separation found in the seasonal patterns of sea level (Sect. 3.1), which may be explained by the fact that the IOD evolution is locked to the seasonal changes (Toshio et al., 2003).

Concurrence of ENSO and IOD extremes may strengthen SLAs. For instance, in 1997 when both MEI and DMI gained large positive values, the sea level in the Malacca Strait dropped more than $11 \mathrm{~cm}$ on average (Fig. 7). The sea level decrease during 1994 was less than in 1997 due to the fact that the El Niño event in 1994 was slightly weaker. The multiple linear regression analysis indicated that sea level variabilities induced by the ENSO and the IOD were 7 and $5 \mathrm{~cm}$, 
respectively, in 1997, whilst ENSO-related sea level change was $2 \mathrm{~cm}$ smaller in 1994. Sea level drops of about $10 \mathrm{~cm}$ in 1997 were observed at Langkawi, Pinang and Kelang stations (Fig. 6), as these locations are more exposed to the IOD governing region (Fig. 8).

\subsection{Long-term sea level trend}

During 1986-2013, the averaged rates of relative sea level rise in the Malacca Strait and along the east coast of Peninsular Malaysia are deduced as $3.6 \pm 1.6$ and $3.7 \pm 1.1 \mathrm{~mm} \mathrm{yr}^{-1}$, respectively (Table 1 ); these are similar to the rate $3.5 \pm 1.2 \mathrm{~mm} \mathrm{yr}^{-1}$ observed in the Singapore Strait. In comparison, the average relative rate for the east coast of Peninsular Malaysia between 1993 and 2009 is $2.2 \pm 2.0 \mathrm{~mm} \mathrm{yr}^{-1}$ (Table 1), which is consistent with the value of about $2.5 \mathrm{~mm} \mathrm{yr}^{-1}$ shown in Fig. 3 of Peng et al. (2013). However, both relative rates from our study and those of Peng et al. (2013) are roughly $0.5-1.0 \mathrm{~mm} \mathrm{yr}^{-1}$ smaller than the values observed from satellite altimetry (Table 1, this study; Fig. 2 of Peng et al., 2013) for the same period. The difference is mostly due to the vertical motions at tide gauge sites whose average rate has the same magnitude $\left(0.9 \mathrm{~mm} \mathrm{yr}^{-1}\right)$ in the east coast of Peninsular Malaysia (Table 1).

Considering that sea level records from the tide gauges are more accurate locally than satellite altimetry, the continuous observations of VLM are important. Taking into account the VLM, rates of geocentric sea level rise obtained from tide gauges for the 1986-2013 period are $4.4 \pm 3.1 \mathrm{~mm} \mathrm{yr}^{-1}$ in Malacca Strait, and $4.6 \pm 2.5 \mathrm{~mm} \mathrm{yr}^{-1}$ along the east coast of Peninsular Malaysia, as shown in Table 1. For the common period 1993-2009, both the altimetry data and corrected tidal records exhibit similar geocentric sea level rise rates. Observations from satellite displayed the rates $2.7 \pm 1.2 \mathrm{~mm} \mathrm{yr}^{-1}$ (Malacca Strait) and $2.7 \pm 1.6 \mathrm{~mm} \mathrm{yr}^{-1}$ (east coast of the peninsula), whilst these from tide stations demonstrated the rates $3.2 \pm 4.6$ and $3.1 \pm 3.0 \mathrm{~mm} \mathrm{yr}^{-1}$, respectively. These regional rates are similar to the global trends derived from tide gauges $\left(2.8 \pm 0.8 \mathrm{~mm} \mathrm{yr}^{-1}\right.$, Church and White, 2011) and satellite altimetry $\left(3.3 \pm 0.4 \mathrm{~mm} \mathrm{yr}^{-1}\right.$, Nicholls and Cazenave, 2010) for the same period. The above result also suggests that the corrected sea level rise rate is about $25 \%$ faster than the relative rate measured at tide gauges around the peninsula.

Lack of VLM measurements is a common problem in estimating sea level trend from tidal records. A major limitation of the current approach is that the present regional network of GPS stations was sparse and data were only available during 1994-2004, which causes high uncertainty in the geocentric rate derived from tide gauges. In the case of missing data, VLM can be inversely estimated from the difference between the sea level change rates measured by satellites and tide gauges (Fenoglio-Marc et al., 2012; Yildiz et al., 2013), but more vertical motion observations (e.g. IOC, 2012) and improved technique to compute the VLM observed from different GPS locations and during different time frames at the sites of tide stations are needed to enhance this approach.

\section{Conclusions}

Tide gauge records, satellite altimetry and VLM as well as climate proxies are used to quantify sea level trend and variability along the Malaysian peninsula coasts. Allowing for corresponding VLMs $\left(0.8 \pm 2.6\right.$ and $0.9 \pm 2.2 \mathrm{~mm} \mathrm{yr}^{-1}$ uplift) during 1986-2013, geocentric sea level rise rates in the Malacca Strait and along the east coast of Peninsular Malaysia are found to be $4.4 \pm 3.1$ and $4.6 \pm 2.5 \mathrm{~mm} \mathrm{yr}^{-1}$, respectively. For the common period 1993-2009, geocentric sea level rise rates obtained from tide gauges and satellite altimetry along the Malaysian coast are similar, and they are comparable with the global trend.

At interannual scale, sea level variability around Peninsular Malaysia is synchronized with ENSO, whilst variations with IOD are observed mainly along the Malacca Strait. Sea level falls coincide with El Niño events, whilst the rises are correlated with La Niña episodes; both extremes are in the range of $\pm 6 \mathrm{~cm}$. The interannual SLAs are correlated with MEI with a coefficient of -0.63 at both side of the peninsula. In the Malacca Strait, sea level variability in the range of $\pm 5 \mathrm{~cm}$ is further correlated with DMI with coefficient -0.57 . At annual scale, SLAs around Peninsular Malaysia are mainly monsoon-driven, of the order of $5-25 \mathrm{~cm}$. Sea levels at eastern and western coasts respond differently to the Asian monsoon, having a prevailing semi-annual cycle in the Malacca Strait, due to the SAI monsoon, but an annual cycle in the remaining region, mostly due to the EAWP monsoon. At seasonal to interannual scales, we observe separation of the sea level patterns between the Raffles Lighthouse and Tanjong Pagar stations, likely caused by a dynamic constriction in the narrowest part of Singapore Strait.

Acknowledgements. We appreciate persistent and kind encouragement of J. Huthnance. Comments and constructive suggestions from five reviewers are gratefully acknowledged. We thank B. Thompson, C. Hengkek, V. M. Tue and E. Hill for their useful comments. Thanks are extended to the staff of Copernicus Production Office for their nice support during the preparation and revision of manuscript.

Edited by: J. M. Huthnance

\section{References}

Altamimi, Z., Collilieux X., and Métivier, L.: ITRF2008: an improved solution of the international terrestrial reference frame, $\mathrm{J}$ Geodesy, 85, 457-473, doi:10.1007/s00190-011-0444-4, 2011.

Aparna, S. G., McCreary, J. P., Shankar, D., and Vinayachandran, P. N.: Signatures of Indian Ocean dipole and El Niño-Southern 
Oscillation events in sea level variations in the Bay of Bengal, J. Geophys. Res., 117, C10012, doi:10.1029/2012JC008055, 2012. Becker, M., Meyssignac, B., Letetrel, C., Llovel, W., Cazenave, A., and Delcroix, T.: Sea level variations at tropical Pacific islands since 1950, Global Planet. Change, 80-81, 85-98, doi:10.1016/j.gloplacha.2011.09.004, 2012.

Bos, M. S., Williams, S. D. P., Araujo, I. B., and Bastos, L.: The effect of temporal correlated noise on the sea level rate and acceleration uncertainty, Geophys. J. Int., 196. 1423-1430, doi:10.1093/gji/ggt481, 2014.

Chen, H., Tkalich, P., Malanotte-Rizzoli, P., and Wei, J.: The forced and free response of the South China Sea to the large-scale monsoon system, Ocean Dynam., 62, 377-393, doi:10.1007/s10236011-0511-7, 2012.

Cheng, X. and Qi, Y.: Trends of sea level variations in the South China Sea from merged altimetry data, Global Planet. Change, 57, 371-382, doi:10.1016/j.gloplacha.2007.01.005, 2007.

Church, J. A. and White, N. J.: A 20th century acceleration in global sea-level rise, Geophys. Res. Lett., 33, L01602, doi:10.1029/2005GL024826, 2006.

Church, J. A. and White, N. J.: Sea-level rise from the late 19 th to the early 21 st century, Surv. Geophys., 32, 585-602, doi:10.1007/s10712-011-9119-1, 2011.

Church, J. A., White, N. J., Coleman, R., Lambeck, K., and Mitrovica, J. X.: Estimates of the regional distribution of sea-level rise over the 1950 to 2000 period, J. Climate, 17, 2609-2625, doi:10.1175/1520-0442(2004)017<2609:EOTRDO>2.0.CO;2, 2004.

Church, J. A., White, N. J., and Hunter, J. R.: Sea-level rise at tropical Pacific and Indian Ocean islands, Glob. Planet. Change, 53, 155-168, doi:10.1016/j.gloplacha.2006.04.001, 2006.

Clarke, A. J. and Liu, X.: Interannual sea level in the northern and eastern Indian Ocean, J. Phys. Oceanogr., 24, 1224-1235, doi:10.1175/1520-0485(1994)024<1224:ISLITN>2.0.CO;2, 1994.

Ding, Y. and Johnny, C. L. C.: The East Asian summer monsoon: an overview, Meteorol. Atmos. Phys., 89, 117-142, doi:10.1007/s00703-005-0125-z, 2005.

Douglas, B. C.: Sea level change in the era of the recording tide gauge, in: Sea Level Rise: History and Consequence, edited by: Douglas, B. C., Kearney, M. S., and Leatherman, S. P., International Geophysical Series, 75, Academic Press, 37-64, 2001.

Fenoglio-Marc, L., Braitenberg, C., and Tunini, L.: Sea level variability and trends in the Adriatic Sea in 1993-2008 from tide gauges and satellite altimetry, Phys. Chem. Earth, 40-41, 47-58, doi:10.1016/j.pce.2011.05.014, 2012.

Foster, G. and Brown, P. T.: Time and tide: analysis of sea level time series, Clim Dyn., 45, 291-308, doi:10.1007/s00382-014-22243, 2014.

García-Lafuente, J., Del Río, J., Alvarez Fanjul, E., Gomis, D., and Delgado, J.: Some aspects of the seasonal sea level variations around Spain, J. Geophys. Res., 109, C09008, doi:10.1029/2003JC002070, 2004.

Goswami, B. N., Krishnamurthy, V., and Annmalai, H.: A broadscale circulation index for the interannual variability of the Indian summer monsoon, Q. J. Roy. Meteorol. Soc., 125, 611-633, doi:10.1002/qj.49712555412, 1999.
Hay, C. C, Morrow, E., Kopp, R. E., and Mitrovica, J. X.: Probabilistic reanalysis of twentieth-century sea-level rise, Nature, 517 (22 Jan 2015), 481-484, doi:10.1038/nature14093, 2015.

Holgate, S. J., Matthews, A., Woodworth, P. L., Rickards, L. J., Tamisiea, M. E., Bradshaw, E., Foden, P. R., Gordon, K. M., Jevrejeva, S., and Pugh, J.: New data systems and products at the permanent service for mean sea level, J. Coastal Res., 29, 493-504, doi:10.2112/jcoastres-d-12-00175.1, 2013.

IOC: The Global Sea Level Observing System Implementation Plan 2012, GOOS Rep. No.194 (JCOMM Technical Rep. No. 66), UNESCO, 44 pp., 2012.

IPCC: Climate Change 2013: The Physical Science Basis, Contribution of Working Group I to the Fifth Assessment Report of the Intergovernmental Panel on Climate Change, edited by: Stocker, T. F., Qin, D., Plattner, G.-K., Tignor, M., Allen, S. K., Boschung, J., Nauels, A., Xia, Y., Bex, V., and Midgley, P. M., Cambridge University Press, Cambridge, United Kingdom and New York, USA, 1535 pp., 2013.

Jevrejeva, S., Moore, J. C., Grinsted, A., and Woodworth, P. L.: Recent global sea level acceleration started over 200 years ago?, Geophys. Res. Lett., 35, L08715, doi:10.1029/2008GL033611, 2008.

Laing, A. and Evans, J. L.: Introduction to Tropical Metorology, 2nd Edn., COMET Program, available at: http://www.goes-r.gov/ users/comet/tropical/textbook_2nd_edition/index.htm (last access: 14 March 2014), University Corporation for Atmospheric Research, 2011.

Lau, K.-M., Wu, H.-T., and Yang, S.: Hydrologic processes associated with the first transition of the Asian Summer Monsoon: a pilot satellite study, B. Am. Meteorol. Soc., 79, 1871-1882, doi:10.1175/1520-0477(1998)079<0061:APGTWA>2.0.CO;2, 1998.

L'Heureux, M. L., Lee, S., and Lyon, B.: Recent multidecadal strengthening of the Walker circulation across the tropical $\mathrm{Pa}$ cific, Nat. Clim. Change, 3, 571-576, doi:10.1038/nclimate1840, 2013.

Li, J. and Zeng, Q.: A unified monsoon index, Geophys. Res. Lett., 29, 1274, doi:10.1029/2001GL013874, 2002.

Merrifield, M. A.: A shift in western tropical Pacific sea level trends during the 1990s, J. Climate, 24, 4126-4138, doi:10.1175/2011JCLI3932.1, 2011.

Meyssignac, B. and Cazenave, A.: Sea level: A review of presentday and recent-past changes and variability, J. Geodyn., 58, 96109, doi:10.1016/j.jog.2012.03.005, 2012.

Meyssignac, B., Becker, M., Llovel, W., and Cazenave, A.: An assessment of two-dimensional past sea level reconstructions over 1950-2009 based on tide-gauge data and different input sea level grids, Surv. Geophys., 33, 945-972, doi:10.1007/s10712-0119171-x, 2012.

Murtugudde, R., McCreary, J. P., and Busalacchi, A. J.: Oceanic processes associated with anomalous events in the Indian Ocean with relevance to 1997-1998, J. Geophys. Res., 105, 3295-3306, 2000.

Nerem, R. S., Leuliette, E., and Cazenave, A.: Present-day sea-level change: a review, Ext. Geophys. Clim. Env., 338, 1077-1083, doi:10.1016/j.crte.2006.09.001, 2006.

Nerem, R. S., Chambers, D., Choe, C., and Mitchum, G. T.: Estimating mean sea level change from the TOPEX 
and Jason altimeter missions, Mar. Geod., 33, 435-446, doi:10.1080/01490419.2010.491031, 2010.

Nicholls, R. J. and Cazenave, A.: Sea-level rise and it impact on coastal zones, Science, 328, 1517-1519, doi:10.1126/science.1185782, 2010.

Nidheesh, A. G., Lengaigne, M., Vialard, J., Unnikrishnan, A. S., and Dayan, H.: Decadal and long-term sea level variability in the tropical Indo-Pacific Ocean, Clim. Dyn., 41, 381-402, doi:10.1007/s00382-012-1463-4, 2013.

Palanisamya, H., Cazenave, A., Meyssignac, B., Soudarin, L., Wöppelmann, G., and Becker, M.: Regional sea level variability, total relative sea level rise and its impacts on islands and coastal zones of Indian Ocean over the last sixty years, Glob. Planet. Change, 116, 54-67, 2014.

Peltier W. R.: Global glacial isostasy and the surface of the Ice-Age Earth: The ICE-5G(VM2) model and GRACE, Ann. Rev. Earth. Planet. Sci., 32,111-149, doi:10.1146/annurev.earth.32.082503.144359, 2004.

Peng, D., Palanisamy, H., Cazenave, A., and Meyssignac, B.: Interannual sea level variations in the South China Sea over 1950-2009, Mar. Geod., 36, 164-182, doi:10.1080/01490419.2013.771595, 2013.

Qiu, B. and Chen, S.: Multidecadal sea level and gyre circulation variability in the northwestern tropical Pacific Ocean. J. Phys. Oceanogr., 42, 193-206, 2011.

Qu, T., Kim, Y. Y., Yaremchukm, M., Tozuka, T., Ishida, A., and Yamagata, T.: Can Luzon Strait transport play a role in conveying the impact of ENSO to the South China Sea? J. Clim., 17, 3644-3657, doi:10.1175/15200442(2004)017<3644:CLSTPA>2.0.CO;2, 2004.

Rong, Z., Liu, Y., Zong, H., and Cheng, Y.: Interannual sea level variability in the South China Sea and its response to ENSO, Global Planet. Change, 55, 257-272, doi:10.1016/j.gloplacha.2006.08.001, 2007.

Saji, N. H., Goswami, B. N., Vinayachandran, P. N., and Yamagata, T.: A dipole mode in the tropical Indian Ocean, Nature, 401, 360363, 1999.

Santamaria-Gomez, A., Gravelle, M., Collilieux, X., Guichard, M., Martin Miguez, B., Tiphaneau, P., and Wöppelmann, G.: Mitigating the effects of vertical land motion in tide gauge records using a state-of-the-art GPS velocity field, Global Planet. Change, 98-99, 6-17, doi:10.1016/j.gloplacha.2012.07.007, 2012.

Simons, W. J. F., Socquet, A., Vigny, C., Ambrosius, B. A. C., Haji Abu, S., Promthong, C., Subarya, C., Sarsito, D. A., Matheussen, S., Morgan, P., and Spakman, W.: A decade of GPS in Southeast Asia: resolving Sundaland motion and boundaries, J. Geophys. Res., 112, B06420, doi:10.1029/2005JB003868, 2007.

Sreenivas, P., Gnanaseelan, C., and Prasad, K. V. S. R.: Influence of El Niño and Indian Ocean Dipole on sea level variability in the Bay of Bengal, Global Planet. Change, 80-81, 215-225, doi:10.1016/j.gloplacha.2011.11.001, 2012.

Stammer, D., Cazenave, A., Ponte, R. M., and Tamisiea, M. E.: Causes for contemporary regional sea level changes, Annu. Rev. Mar. Sci., 5, 21-46, doi:10.1146/annurev-marine-121211172406, 2013.

Tamisiea, M. E. and Mitrovica, J. X.: The moving boundaries of sea level change: Understanding the origins of geographic variability, Oceanography 24, 24-39, doi:10.5670/oceanog.2011.25, 2011.
Tan, C. K., Ishizaka, J., Matsumura, S., Yusoff, F. M., and Mohamed, M. I. H.: Seasonal variability of SeaWiFS chlorophyll a in the Malacca Straits in relation to Asian monsoon, Cont. Shelf Res., 26, 168-178, doi:10.1016/j.csr.2005.09.008, 2006.

Tkalich, P., Vethamony, P., Babu, M. T., and Malanotte-Rizzoli, P.: Storm surges in the Singapore Strait due to winds in the South China Sea, Nat. Hazards, 66, 1345-1362, doi:10.1007/s11069012-0211-8, 2012.

Tkalich, P., Vethamony, P., Luu, Q.-H., and Babu, M. T.: Sea level trend and variability in the Singapore Strait, Ocean Sci., 9, $293-$ 300, doi:10.5194/os-9-293-2013, 2013.

Toshio, Y., Behera, S. K., Rao, S. A., Guan, Z., Ashok, K., and Saji, H. N.: Comments on "Dipoles, Temperature Gradients, and Tropical Climate Anomalies”, B. Am. Meteorol. Soc., 84, 14181422, doi:10.1175/BAMS-84-10-1418, 2003.

Trenberth, K. E. and Hurrell, J. W.: Decadal atmosphereocean variations in the Pacific, Clim. Dyn. 9, 303-319, doi:10.1007/BF00204745, 1994.

Trisirisatayawong, I., Naeije, M., Simons, W., and Fenoglio-Marc, L.: Sea level change in the Gulf of Thailand from GPS-corrected tide gauge data and multi-satellite altimetry, Global Planet. Change, 76, 137-151, doi:10.1016/j.gloplacha.2010.12.010, 2011.

Tsimplis, M. N. and Woodworth, P. L.: The global distribution of the seasonal sea level cycle calculated from coastal tide gauge data, J. Geophys. Res., 99, 16031-16039, doi:10.1029/94JC01115, 1994.

Vinayachandran, P. N., Saji, N. H., and Toshio, Y.: Response of the equatorial Indian Ocean to an unusual wind event during 1994, Geophys. Res. Lett., 26, 1613-1616, doi:10.1029/1999GL900179, 1999.

Vinogradov, S. V. and Ponte, R. M.: Annual cycle in coastal sea level from tide gauges and altimetry, J. Geophys. Res., 115, C04021, doi:10.1029/2009JC005767, 2010.

Vinogradov, S. V. and Ponte, R. M.: Low-frequency variability in coastal sea level from tide gauges and altimetry, J. Geophys. Res., 116, C07006, doi:10.1029/2011JC007034, 2011.

Wahl, T., Jensen, J., and Frank, T.: On analysing sea level rise in the German Bight since 1844, Nat. Hazards Earth Syst. Sci., 10, 171-179, doi:10.5194/nhess-10-171-2010, 2010.

Wang, B. and Fan, Z.: Choice of South Asian summer monsoon indices, B. Am. Meteorol. Soc., 80, 629-638, 1999.

Wang, B., Huang, F., Wu, Z., Yang, J., Fu, X., and Kikuchi, K.: Multi-scale climate variability of the South China Sea monsoon: a review, Dynam. Atmos. Oceans, 47, 15-37, doi:10.1016/j.dynatmoce.2008.09.004, 2009.

Wang, C., Wang, W., Wang, D., and Wang, Q.: Interannual variability of the South China Sea associated with El Niño, J. Geophys. Res.-Oceans, 111, 2156-2202, doi:10.1029/2005JC003333, 2006.

Wolter, K. and Timlin, M. S.: Monitoring ENSO in COADS with a seasonally adjusted principal component index, in: Proceedings of the 17th Clim. Diagn. Workshop, Norman, OK, NOAA/NMC/CAC, NSSL, Oklahoma Climate Survey, CIMMS and School of Meteorology, University Oklahoma, 52-57, 1993.

Wolter, K. and Timlin, M. S.: Measuring the strength of ENSO events - how does 1997/98 rank?, Weather, 53, 315-324, doi:10.1002/j.1477-8696.1998.tb06408.x, 1998. 
Wöppelman, G., Martin Miguez, B., Bouin, M.-N., and Altamimi, Z.: Geocentric sea-level trend estimates from GPS analyses at relevant tide gauges world-wide, Global Planet. Change, 57, 396-406, doi:10.1016/j.gloplacha.2007.02.002, 2007.

Wöppelmann, G., Letetrel, C., Santamaria, A., Bouin, M.-N., Collilieux, X., Altamimi, Z., Williams, S. D. P., and Martin Miguez, B.: Rates of sea-level change over the past century in a geocentric reference frame, Geophys. Res. Lett., 36, L12607, doi:10.1029/2009GL038720, 2009.

Wöppelmann, G., Marcos, M., Santamaria-Gomez, A., MartínMíguez, B., Bouin, M. N., and Gravell, M.: Evidence for a differential sea level rise between hemispheres over the twentieth century, Geophys. Res. Lett., 41, 1639-1643, doi:10.1002/2013GL059039, 2014.
Wyrtki, K.: Physical Oceanography of the Southeast Asian Waters, Scientific Results of Maritime Investigations of the South China Sea and Gulf of Thailand 1959-1961, NAGA Report 2, Scripps Institute of Oceanography, 195 pp., 1961.

Yildiz, H., Andersen, O. B., Simav, M., Aktug, B., and Ozdemir, S.: Estimates of vertical land motion along the southwestern coasts of Turkey from coastal altimetry and tide gauge data, Adv. Space Res., 51, 1572-1580, doi:10.1016/j.asr.2012.11.011, 2013. 